Hadith As Scripture 
This page intentionally left blank 


\title{
Hadith As Scripture
}

\section{Discussions on the Authority of Prophetic Traditions in Islam}

\author{
Aisha Y. Musa
}




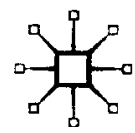

HADĪTH AS SCRIPTURE

Copyright () Aisha Y. Musa, 2008.

Softcover reprint of the hardcover 1st edition 2008 978-0-230-60535-0

All rights reserved. No part of this book may be used or reproduced in any manner whatsoever without written permission except in the case of brief quotations embodied in critical articles or reviews.

First published in 2008 by

PALGRAVE MACMILLAN TM

175 Fifth Avenue, New York, N.Y. 10010 and

Houndmills, Basingstoke, Hampshire, England RG21 6XS

Companies and representatives throughout the world.

PALGRAVE MACMILLAN is the global academic imprint of the Palgrave Macmillan division of St. Martin's Press, LLC and of Palgrave Macmillan Ltd. Macmillan ${ }^{\circledR}$ is a registered trademark in the United States, United Kingdom and other countries. Palgrave is a registered trademark in the European Union and other countries.

ISBN 978-1-349-37280-5 ISBN 978-0-230-61197-9 (eBook)

DOI 10.1057/9780230611979

Library of Congress Cataloging-in-Publication Data

Musa, Aisha Y., 1958-

Hadith as scripture : discussions on the authority of prophetic traditions in Islam / by Aisha Y. Musa.

p. cm.

Includes bibliographical references.

1. Hadith-Evidences, authority, etc. 2. Hadith-Criticism, interpretation, etc. I. Title.

BP136.4.M85 2008

297.1'2401-dc22

2007041183

A catalogue record for this book is available from the British Library.

Design by Newgen Imaging Systems (P) Ltd., Chennai, India.

First edition: May 2008

109876554321 


\section{O N T E N T S}

Transliteration and Dating

Introduction: The Issue of Authority and Its

Ongoing Importance

Part 1 Discussions in the Formative Period

One The Early Controversies: Sources and Issues

Two Al-Shāfíi and Ibn Qutayba: Prophetic Reports as Revelation

Three Later Works on the Problem of the Hadith

Part 2 Discussions in the Contemporary Period

Four The Question of Authority in the Modern Period 83

Five Internet Resources and Discussions 99

\section{Part 3 The Book of the Amalgamation of Knowledge}

Six A Translation of Kitāb Jimā'al-'ilm

List of Qur'ānic Verses

Notes

Bibliography 
This page intentionally left blank 


\section{T R A N S L I T E R A T I O N}

\section{A N D D A T I N G}

For rendering Arabic words such as Hadith in English, I have followed the transliteration system used by the International Journal of Middle Eastern Studies. The Islamic calendar dates from the Prophet Muhammad's migration (Hijra) from Mecca to Medina in 622 CE. Historical figures and classical authors are identified by their death dates using both Hijri (AH) and Gregorian (CE) years. For example, Muhammad ibn Idrīs al-Shāfi $i$ (d. 204/820) died in the year $204 \mathrm{AH}$, which corresponds to $820 \mathrm{CE}$. 